\title{
SISTEM MONITORING PERKULIAHAN DI UNIVERSITAS NUSANTARA PGRI KEDIRI
}

\author{
Danang Wahyu Widodo ${ }^{1}$, Julian sahertian ${ }^{2}$, Ahmad Bagus Setiawan ${ }^{3}$ \\ Teknik Informatika, Universitas Nusantara PGRI Kediri \\ Jl. KH. Achmad Dahlan Gg. 1 Mojoroto Kota Kediri \\ E-mail: danangwahyuwidodo@unpkediri.ac.id, juliansahertian@unpkediri.ac.id, \\ Ahmadbagus@unpkediri.ac.id
}

\begin{abstract}
Abstraks
Lembaga Pendidikan merupakan sarana sebagai wadah mencetak generasi yang tangguh, berpendidikan dan berkopetensi dibidangnya masing-masing, Universitas Nusantara PGRI Kediri merupakan salah satu Lembaga pendidikan di Kota Kediri yang mengemban tugas sebagai pencetak generasi yang mempunyai bakat, sistem pengajaran harus menjadi prioritas, agar mahasiswa mendapatkan pengajaran sesuai dengan silabus yang sudah ditentukan. Maka kami memberikan sistem sebagai monitoring dosen dalam memebrikan pengajaran kepada mahasiswa dan dapat kami jadikan bahan evaluasi dalam memberikan penilaian kepada dosen.
\end{abstract}

Kata Kunci: Monitoring, Pengajaran, Mahasiswa

\section{PENDAHULUAN}

\subsection{Latar Belakang.}

Sistem Monitoring selalu di adakan setiap menjelang Akhir pengajaran dan sistem yang selama ini di jalankan adalah dengan menyebarkan form penilaian kepada mahasiswa dengan populasi dan sampel yang sudah ditentukan, dan mengumpulkan Jurnal Perkuliahan.

Sistem yang tersebut dinilai kurang cepat dalam memberikan sebuah data untuk bahan evaluasi sistem perkuliahan di Universitas Nusantara PGRI Kediri.

Pendataan melaui form akan menyita banyak waktu dan akan mempersulit pendataan dari biro Penjamin Mutu dan Sumber daya Manusia, karena kita tahu bahwa Universitas Nusantara PGRI Kediri Memiliki 5 Fakultas dan sebaran 22 Program studi, dengan terbatasnya SDM di Biro Penjamin Mutu dan Sumber Daya manusia maka perlu di adakan sebuah sistem yang dapat membantu pelaksanaan monitoring perkuliahan di Universitas Nusantara PGRI Kediri.

Dengan pengamatan permasalah diatas, kami merencanakan sistem ini dapat secara langsung monitoring keaktifan dosen pengajar melaui materimateri yang di berikan kepada mahasiswa.

\subsection{Rumusan masalah}

Berdasarkan latar belakang diatas maka permasalahan yang dapat dirumuskan pada penelitian ini yaitu :

1. Bagaimana menerapkan Sistem Monitoring Perkuliahan Di Universitas Nusantara Pgri Kediri?

2. Bagaimana menciptakan sistem yang mampu memonitoring perkuliahan di Universitas Nusantara PGRI Kediri?

\subsection{Batasan Masalah}

Pada penelitian ini ditetapkan beberapa hal yang menjadi batasan masalah diantaranya adalah sebagai berikut :

1. Penelitian akan dilakukan pada lingkup Universitas Nuasnatara PGRI Kediri.

2. Sistem yang digunakan adalah monitoring .

3. Bahasa pemrograman yang digunakan adalah PHP dan database MySql

4. Data yang diperlukan adalah Satuan Acara Perkuliahan, Presensi, dan aktifitas Mahasiswa

\section{PEMBahasan}

Menguraikan hasil analisis kualitatif dan/atau kuantitatif dengan penekanan pada jawaban atas permasalahan. Isi dari pembahasan ini memuat segala sesuatu tentang kegiatan yang dilakukan dalam makalah. Mulai dari konsep, perancangan, hipotesis (bila ada), percobaan, data pengamatan, dan hasil dari data pengamatan yang ada.

Isi didukung dengan gambar, tabel, dan persamaan yang dirujuk dalam naskah.

\subsection{Metode Penelitian}

Metode yang digunakan untuk pengembangan sistem yang akan dibuat adalah metode waterfall. Metode waterfall adalah sebuah metode pengembangan sistem atau software yang bersifat sekuensial linier yaitu proses pengerjaan dari suatu sistem dilakukan secara berurutan dan sistematis. Berikut ini merupakan tahapan - tahapan dari metode waterfall. 


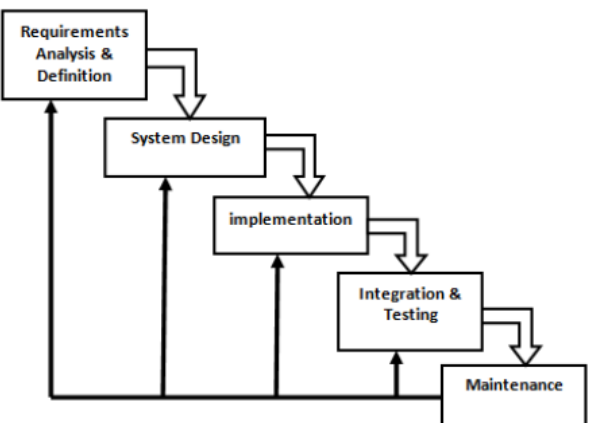

\section{Gambar 1. Tahapan Dalam Model Waterfall}

Secara garis besar metode waterfall mempunyai tahapan sebagai berikut ini :

\section{Analisa dan Definisi Kebutuhan Requirement Analysis \& Definition}

Pada tahap ini dilakukan analisa terhadap kebutuhan sistem baik software dan hardware.

Dalam tahap ini juga dilakukan proses pengumpulan data dengan cara melakukan studi literatur, wawancara, observasi dan dokumentasi mengenai data - data mahasiswa yang diperlukan. Tahapan ini akan menghasilkan dokumen user requirement atau data yang berhubungan dengan keinginan user dalam pembuatan sistem. Dokumen ini yang akan menjadi acuan dalam tahap desain sistem.

\section{Desain Sistem (System Design)}

Tahap desain sistem akan menerjemahkan syarat kebutuhan ke sebuah perancangan perangkat lunak sebelum dibuat coding. Pada proses ini dibuat perancangan arsitektur perangkat lunak, struktur data, representasi interface, dan algoritma prosedural.

\section{Pembuatan Sistem (Implementation)}

Pada tahap ini dilakukan penerjemahan dari proses desain kedalam bahasa yang bisa dikenali oleh komputer. Dalam proses ini dilakukan pembuatan program (coding) sesuai dengan sistem. Bahasa pemrograman yang digunakan dalam sistem ini adalah PHP, database yang digunakan untuk menyimpan data adalah MySQL.

\section{Integrasi dan Pengujian Sistem(Integration \& Testing)}

Pada tahap ini dilakukan pengujian terhadap program yang telah dibuat dengan cara melakukan uji coba terhadap semua fungsi dan modul pada sistem.

\section{Pemeliharaan (Maintenance)}

Sistem yang telah dibuat dapat mengalami perubahan yang disebabkan kebutuhan perkembangan fungsional dari user atau disebabkan penyesuaian terhadap perkembangan lingkungan seperti harware, software, peripheral, atau sistem operasi baru.

\subsection{Tinjauan Pustaka \\ a. Konsep Dasar Sistem Informasi}

Telah diketahui bahwa informasi adalah sebuah bahan penting bagi manajemen. Sistem informasi dalam sebuah organisasi dibatasi oleh data yang dapat diperoleh, biaya untuk pengadaan, pengolahan dan penyimpanan dan sebagainya.

Sebuah sistem informasi berdasarkan komputer biasanya dapat mengurangi biaya sekaligus meningkatkan kemampuan dan prestasi sistem informasi.

Menurut Jogiyanto H.M (1995:697) dalam Andy Indra Rinaldi (2003:8) mendefiniskan sistem informasi adalah : Suatu sistem didalam suatu organisasi yang merupakan kombinasi dari orangorang fasilitas, teknologi, media, prosedurprosedur dan pengendalian yang ditujukan untuk mendapatkan jalur komunikasi penting memproses tipe transaksi rutin tertentu, memberi sinyal kepada manajemen dan yang lainnya terhadap kejadiankejadian intenal dan eksternal yang penting dan menyediakan suatu dasar informasi untuk pengambilan keputusan yang cerdik.

Andri Kristanto (2003,11), mendefinisikan sistem informasi merupakan kumpulan dari perangkat keras dan perangkat lunak komputer serta perangkat manusia yang akan mengolah data menggunakan perangkat keras dan perangkat lunak tersebut.

Menurut Aji Supriyanto (2005:243) sistem informasi adalah sistem didalam suatu organisasi, yang mempertemukan kebutuhan pengolahan transaksi harian, mendukung operasi bersifat manajerial dan kegiatan strategi dari suatu organisasi dan menyediakan pihak luar tertentu dengan laporan-laporan yang diperlukan. Selain itu sistem informasi dapat didefinisikan sebagai berikut :

a. Suatu sistem yang dibuat oleh manusia yang terdiri komponenkomponen dalam organisasi untuk mencapai suatu tujuan yaitu menyajikan informasi.

b. Sekumpulan prosedur organisasi yang pada saat dilaksanakan akan memberikan informasi bagi pengambil keputusan dan atau untuk mengendalikan organisasi.

c. Suatu sistem didalam suatu organisasi yang mempertemukan kebutuhan pengolahan transaksi, mendukung operasi, bersifat manajerial dan kegiatan strategi dari suatu organisasi dan menyediakan pihak luar tertentu dengan laporan-laporan yang diperlukan.

Sistem informasi dapat terdiri dari komponenkomponen yang disebut dengan istilah blok bangunan (building block), yaitu blok masukan (input block), blok model (model block), blok keluaran (output block), blok teknologi (technology block), blok dasar data (database block) dan blok kendali (control block). Sebagai suatu sistem, keenam blok tersebut masing-masing saling 
berinteraksi satu dengan yang lainnya membentuk satu kesatuan untuk mencapai sasarannya.

a. Blok masukan : merupakan input yang mewakili data yang masuk kedalam sistem informasi yang dapat berupa dokumen-dokumen dasar.

b. Blok model : terdiri dari kombinasi prosedur, logika dan model matematik yang akan memanipulasi data input dan data yang tersimpan di basis data dengan cara yang sudah tertentu untuk menghasilkan keluaran yang diinginkan.

c. Blok keluaran : merupakan keluaran yang merupakan informasi yang berkualitas dan dokumentasi yang berguna.

d. Blok teknologi : digunakan untuk menerima input, menjalankan model, menyimpan dan mengakses data, menghasilkan dan mengirimkan keluaran dan membantu pengendalian dari sistem keseluruhan. Teknologi itu sendiri terdiri dari 2 bagian utama, yaitu perangkat software dan hardware.

e. Blok basis data : kumpulan dari data yang saling berhubungan satu dengan yang lainnya, tersimpan di perangkat keras komputer dan digunakan perangkat lunak untuk memanipulasinya.Blok kendali : dirancang dan diterapkan untuk mencegah hal-hal yang dapat merusak sistem ataupun kesalahan-kesalahan yang dapat terjadi sewaktu sistem diimplementasikan.

\section{b. Sistem Informasi}

Sistem Informasi adalah pengaturan orang, data, proses dan teknologi informasi yang berinteraksi untuk mengumpulkan memproses, menyimpan dan menyediakan sebagai output informasi yang diperlukan untuk mendukung sebuah organisasi

Banyak orgasnisasi menganggap sistem informasi dieprlukan untuk memiliki kemampuan bersaing atau memperoleh keuntungan persaingan. Sistem informasi dapat diklasifikasikan berdasarkan fungsinya yaitu Transaction Processing System, Management Information System, Desision Support System, Executive Information System Expert System, Communication and Colaboration System dan Office Automation System.

Dalam arti yang sangat luas, istilah sistem informasi yang sering digunakan merujuk kepada interaksi antara orang, proses algoritmik, data, dan teknologi. Dalam pengertian ini, istilah ini digunakan untuk merujuk tidak hanya pada penggunaan organisasi teknologi informasi dan komunikasi (TIK), tetapi juga untuk cara di mana orang berinteraksi dengan teknologi ini dalam mendukung proses bisnis

\section{c. Pengertian Web}

Pada awalnya aplikasi web dibangun dengan hanya menggunakan bahasa yang disebut HTML (HyperText Markup Langauge).Pada perkembangan berikutnya, sejumlah skrip dan objek dikembangkan untuk memperluas kemampuan HTML seperti PHP dan ASP pada skrip dan Apllet pada objek. Aplikasi web dapat dibagi menjadi dua jenis yaitu aplikasi web statis dan dinamis. Web statis dibentuk dengan menggunakan HTML.Kekurangan aplikasi seperti ini terletak pada keharusan untuk memelihara program secara terus menerus untuk mengikuti setiap perkembangan yang terjadi.Kelemahan ini diatasi oleh model aplikasi web dinamis. Pada aplikasi web dinamis, perubahan informasi dalam halamanweb dilakukan tanpa perubahan program tetapi melalui perubahan data.(Endang dafa,2012)

\section{d. PHP}

PHP adalah salah satu bahasa Server-side yang didesain khusus untuk aplikasi web. PHP dapat disisipkan diantara bahasa HTML dan karena bahasa Server-side, maka bahasa PHP akan dieksekusi di server, sehingga yang dikirimkan ke browser adalah "hasil jadi" dalam bentul HTML, dan kode PHP anda tidak akan terlihat. PHP adalah bahasa yang mudah dibuat. Notepad merupakan editor teks yang biasa digunakan. Kode PHP diawali dengan tanda lebih kecil (<) dan diakhiri dengan tanda lebih besar (>).(Sutarman.2007:96)

\subsection{Hasil}

Sistem Monitoring Perkuliahan Di Universitas Nusantara Pgri Kediri, merupakan sistem monitoring dosen terhadap pengajaran yang sudah di tetapkan oleh Program Studi, dan dijalankan sesuai silabus yang sudah dibentuk dan ditetapkan, Unit Penjamin mutu dengan mudah memonitoring kesiapan dosen dalam membeikan perkuliahan.

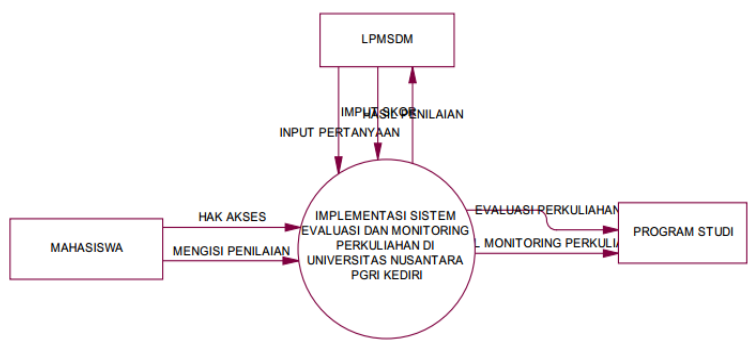

Gambar 2. Context Diagram

Untuk masuk dalam sistim monitoring dosen ataupun pihak penjamin mutu dapat menggunakan hak akses sesuai dengan bagiannya masing-masing, dikarenakan fasilitas yang ada berbeda-beda sesuai kapasitas pengguna..

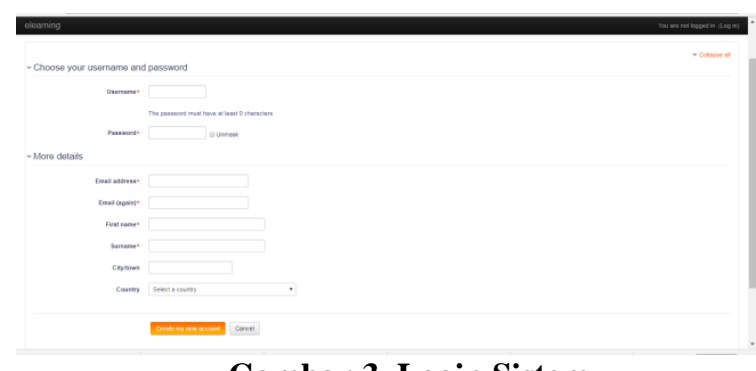


Materi yang diberikan dapat berupa ppt maupun dalam bentuk pdf, untuk memudahkan mahasiswa mempelajari lebih awal materi yang hendak diberikan dikelas, disini dimungkinkan

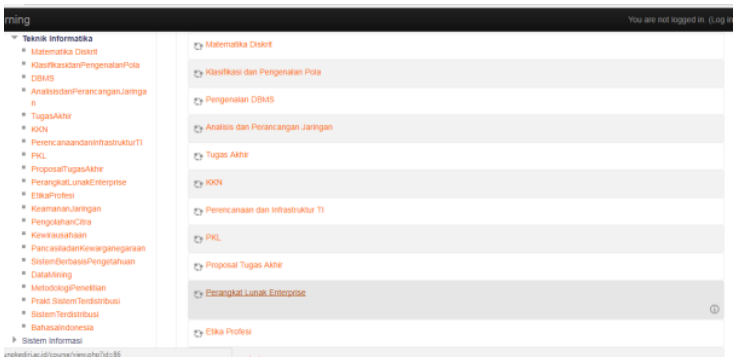

\section{Gambar 4. Materi dosen}

\section{KESIMPULAN}

Sistem Monitoring Perkuliahan Di Universitas Nusantara Pgri Kediri, memberikan kemudahan terhadap mahasiswa maupun lembaga untuk memantau perkuliahan dan mahasiswa dapat dengan mudah mempelajari materi yang hendak diajarkan dalam perkuliahan.

\section{PUSTAKA}

Kadir. Abdul. 2003. Pengenalan Sistem Informasi. Yogyakarta:Penerbit Andi.

McLeod, Raymond Jr. 1996. Sistem Informasi Manajemen. Jilid 1. Jakarta: PT. Ikrar Mandiriabadi.

Anonymous, 2011. Mastering CMS Programming with PHP \& MySQL,2011. Yogyakarta: ANDI

Al Fatta, Hanif. 2007. Analisis dan Perancangan Sistem Informasi. Yogyakarta : Penerbit Andi.

Kusrini . 2007 . Strategi Perancangan dan Pengelolaan Basis Data. Yogyakarta : Penerbit Andi.

Indrajit, R. E. dan Djokopranoto, R., 2006, Manajemen Perguruan Tinggi Modern, Penerbit Andi, Yogyakarta.

Rohman, Fatkhur dan Setiawan, Ahmad Bagus , 2015, Sistem Penilaian Dosen Teladan Menggunakan Metode Saw (Simple Additive Weighting) Di Universitas Nusantara Pgri Kediri: Semnasteknomedia STMIK Yogyakarta 